\title{
Analisis Spasial Pengaruh Alokasi Ruang dan Pola Kepemilikan Lahan terhadap Konversi Lahan Sawah: Studi Kasus Kecamatan Rajeg
}

\author{
Spatial Analysis the Effect of Spatial Patterns and Land Ownership Status \\ on Paddy Field Conversion: A Case Study of Rajeg District
}

\author{
Afan Ray Mahardika ${ }^{1 *}$, Baba Barus ${ }^{2} \&$ Didit Okta Pribadi ${ }^{3}$ \\ ${ }^{1}$ Program Studi Ilmu Perencanaan Wilayah, Sekolah Pascasarjana, Institut Pertanian Bogor, Jalan Meranti \\ Kampus IPB Dramaga, Bogor, Jawa Barat 16680, Indonesia; ${ }^{2}$ Departemen Ilmu Tanah dan Sumberdaya \\ Lahan, Fakultas Pertanian, Institut Pertanian Bogor, Jalan Meranti Kampus IPB Dramaga, Bogor, Jawa Barat \\ 16680, Indonesia; ${ }^{3}$ Balai Konservasi Tumbuhan Kebun Raya Eka Karya Bali, Lembaga Ilmu Pengetahuan \\ Indonesia, Candikuning Baturiti Tabanan, Bali 82191, Indonesia; \\ *Penulis korespondensi e-mail: ray_afan@apps.ipb.ac.id \\ (Diterima: 20 Agustus 2020; Disetujui: 30 Januari 2021)
}

\begin{abstract}
Tangerang Regency is one of the regencies in Banten Province, which has a fairly established agricultural system with fertile land potential for the agricultural sector. The central government has prioritized the regenciy's rice field are as one of the food barns of Indonesia. Rajeg District is one of nine districts in Tangerang Regency that has been designated as a food barns. Land conversion has been a threat in implementing stable and sustainable food security. Significantly, conversion of paddy fields can affect the availability of food and inventory of rice fields. The purpose of this study is to analyze the spatial pattern of land use change conversion using the Landscape Metrics method. Data used in this research are secondary data, including land use maps of 2005, 2012, and 2018, spatial pattern maps of Tangerang Regency Spatial Plan (RTRW) 2011-2031, and maps of land ownership status in Rajeg District. Result of the analysis shows that the largest conversion of land use change occurs in paddy fields into developed land in agricultural areas with unregistered land ownership status (not registered and not certified). The characteristic of spatial pattern of this conversion type covers a wide conversion area with various forms of conversion geometry. Patch density tends to cluster (not fragmented). The built-up land formed in this type of conversion tends to be massive and in the form of clusters.
\end{abstract}

Keywords: conversion of paddy field, land tenure, landscape metric method

\begin{abstract}
ABSTRAK
Kabupaten Tangerang merupakan salah satu kabupaten di Provinsi Banten yang memiliki sistem pertanian yang cukup baik dengan potensi tanah yang subur untuk sektor pertanian. Luas lahan sawahnya diprioritaskan oleh pemerintah pusat sebagai salah satu daerah penyedia pangan di Indonesia. Kecamatan Rajeg merupakan salah satu kecamatan yang ada di Kabupaten Tangerang yang ditetapkan sebagai salah satu dari sembilan kecamatan lainnya sebagai wilayah lumbung pangan. Konversi lahan menjadi ancaman dalam mewujudkan ketahanan pangan yang stabil dan berkelanjutan. Secara signifikan, konversi lahan sawah dapat mempengaruhi ketersediaan pangan dan inventarisasi ketersediaan lahan sawah. Tujuan dari penelitian ini adalah menganalisis pola spasial konversi perubahan penggunaan lahan dengan menggunakan metode Landscape Metrics. Data yang digunakan dalam penelitian ini merupakan data sekunder, diantaranya peta penggunaan
\end{abstract}


lahan tahun 2005, 2012, dan 2018, peta pola ruang Rencana Tata Ruang Wilayah (RTRW) Kabupaten Tangerang tahun 2011-2031, dan peta status kepemilikan lahan di Kecamatan Rajeg. Hasil analisis menunjukkan konversi perubahan penggunaan lahan terluas terjadi pada lahan sawah menjadi lahan terbangun pada kawasan pertanian dengan status kepemilikan lahan unregistered (belum terdaftar dan belum memiliki sertifikat). Karakteristik pola spasial dari jenis konversi tersebut memiliki cakupan wilayah konversi yang luas dengan bentuk geometri konversi yang beraneka ragam. Kerapatan patch cenderung berkumpul (tidak terfragmentasi). Lahan terbangun yang terbentuk pada jenis konversi ini cenderung masif dan berbentuk klaster.

Kata kunci: konversi lahan sawah, landscape metric method, status kepemilikan lahan

\section{PENDAHULUAN}

Kota-kota yang berada di negara berkembang telah mengusulkan pertanian sebagai elemen perkotaan yang penting untuk menghadapi berbagai permasalahan perkotaan diantaranya jumlah penduduk miskin kota yang meningkat, kerawanan pangan perkotaan, dan degradasi lingkungan (Pribadi \& Pauleit, 2016). Kabupaten Tangerang merupakan salah satu kabupaten di Provinsi Banten yang memiliki sistem pertanian yang cukup baik dengan potensi tanah yang subur untuk sektor pertanian. Luas lahan sawahnya diprioritaskan oleh pemerintah pusat sebagai salah satu daerah penyedia pangan di Indonesia.

Kecamatan Rajeg merupakan salah satu kecamatan yang ada di Kabupaten Tangerang yang ditetapkan sebagai salah satu dari sembilan kecamatan lainnya sebagai wilayah lumbung pangan. Pada tahun 2000 jumlah luas lahan sawah di Kecamatan Rajeg seluas 3,254 ha atau sekitar $7.82 \%$ dari total luas lahan sawah di Kabupaten Tangerang (BPS, 2001) dan pada tahun 2017 luas lahan sawah yang tersisa seluas 2,453 ha atau $6.78 \%$ dari total luas sawah di Kabupaten Tangerang. Laju konversi dalam periode 2000-2017 sebesar $1,67 \%$ (BPS, 2018).

Konversi lahan menjadi ancaman dalam mewujudkan ketahanan pangan yang stabil dan berkelanjutan (Pasandaran, 2006). Secara signifikan, konversi lahan sawah dapat mempengaruhi ketersediaan pangan dan inventarisasi ketersediaan lahan sawah irigasi (Pribadi \& Pauleit, 2016). Kebijakan pembangunan yang lebih mengedepankan pembangunan yang bersifat fisik, sektor ekonomi non pertanian dan jumlah penduduk yang terus meningkat pun menyebabkan konversi lahan (Sitorus, 2009) terutama pada lahan sawah (Effendi \& Asmara, 2014).

Rustiadi et al. (2011) menyatakan bahwa dalam hukum ekonomi pasar, konversi lahan cenderung berlangsung dari aktivitas lahan dengan land rent yang lebih rendah ke aktivitas lahan dengan land rent yang lebih tinggi. Hal ini menunjukkan bahwa fenomena konversi lahan akan terus mengarah pada lahan-lahan yang nilai economic land rent nya rendah seperti lahan pertanian ke lahan yang memiliki nilai economic land rent nya relatif tingi seperti permukiman dan industri.

Pada penelitian Handayani (2015), penggunaan lahan sawah memiliki nilai land rent terkecil dibandingkan dengan nilai land rent jenis penggunaan lahan lainnya. Dalam kondisi seperti ini, sektor pertanian cenderung "dikalahkan", karena pemanfaatan lahan untuk tujuan industri dan jasa memberikan land rent yang lebih baik. Akibatnya alih fungsi lahan sawah ke penggunaan non pertanian semakin meningkat. Selain peran economic land rent, ketidakjelasan atau ketidaksesuaian status kepemilikan-penguasaan lahan juga menjadi salah satu faktor pendorong terjadinya konversi penggunaan lahan (Wulandari, 2018) khususnya pada lahan-lahan yang belum terdaftar dan belum tersertifikat, sehingga untuk mencapai tingkat keamanan dalam pemanfaatan lahan perlu menetapkan status kepemilikanpenguasaan lahan (Munadi et al., 2016). 
Undang-Undang Pokok Agraria Tahun 1960 telah mengatur status kepemilikan lahan yang diurus di bawah kelembagaan Badan Pertanahan Nasional dengan tujuan menjamin kepastian hukum oleh pemerintah. Pasal 19 UUPA ayat (1) menyatakan bahwa pemerintah menjamin kepastian hukum dengan melakukan pendaftaran tanah di seluruh wilayah Republik Indonesia.

Upaya strategis dalam pengendalian alih fungsi lahan pertanian dan perlindungan terhadap lahan pertanian produktif telah terakomodir pada Undang-Undang Nomor 41 tahun 2009 tentang Perlindungan Lahan Pertanian Berkelanjutan. Kebijakan ini perlu dijabarkan lebih lanjut oleh Pemerintah Daerah sebagaimana diamanahkan bahwa Provinsi Kabupaten/Kota diharuskan mengidentifikasi lahan pertanian pangan berkelanjutan yang dilanjutkan dengan penetapan kawasan pertanian pangan berkelanjutan melalui Peraturan Daerah Rencana Tata Ruang Wilayah (RTRW), sehingga keberlanjutan lahan pertanian pangan dapat tetap terjaga.

Tujuan penelitian ini untuk mengetahui karakteristik pola spasial dan struktur geometri dari tiap jenis konversi lahan sawah di Kecamatan Rajeg. Analisis kuantitatif digunakan untuk menganalisis karakteristik pola spasial dari tiap jenis konversi lahan sawah menggunakan metode spatial metric. Hasil dari analisis tersebut diharapkan dapat menjadi salah satu acuan pemerintah atau penelitian selanjutnya dalam membuat suatu kebijakan pengendalian sehingga laju konversi lahan sawah dapat diturunkan.

\section{METODOLOGI}

Penelitian ini dilakukan di Kecamatan Rajeg, Kabupaten Tangerang, Provinsi Banten. Kecamatan Rajeg terdiri dari 13 desa/kelurahan [Gambar 1]. Kecamatan Rajeg, merupakan salah satu wilayah yang memiliki potensi pertanian padi sawah di wilayah Kabupaten Tangerang, Provinsi Banten. Secara geografis, Kecamatan Rajeg berada di bagian tengah kabupaten Tangerang. Kecamatan Rajeg Kabupaten Tangerang berjarak $\pm 58 \mathrm{~km}$ dari Ibukota Provinsi Banten dan $\pm 57 \mathrm{~km}$ dari Ibukota Negara Republik Indonesia, DKI Jakarta.

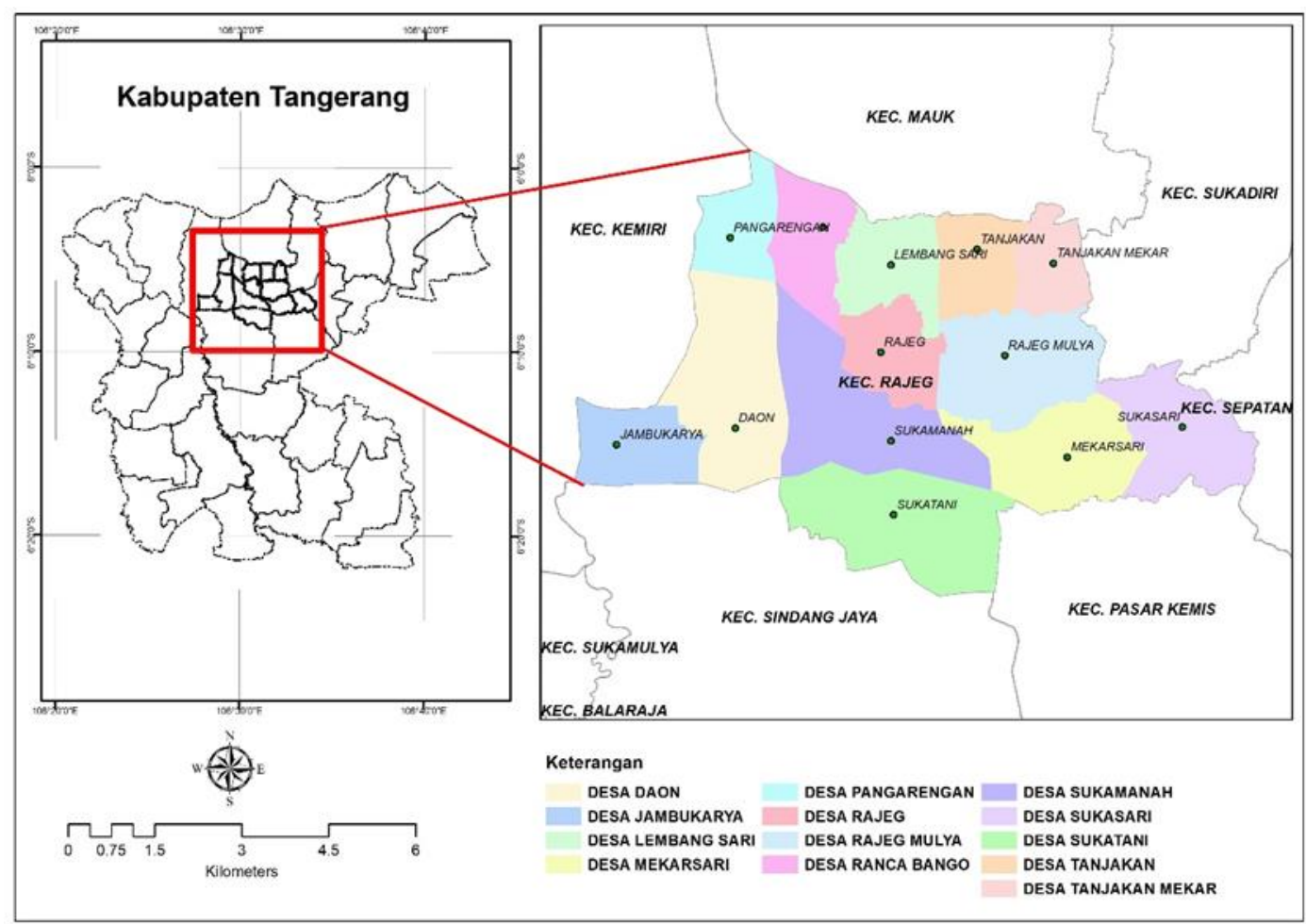

Gambar 1. Lokasi penelitian Kecamatan Rajeg 
Luas wilayah Kecamatan Rajeg adalah 4,725.72 ha atau $4.58 \%$ dari total luas wilayah Kabupaten Tangerang. Wilayah terluas berada di desa Sukatani yaitu seluas 594.79 ha atau 12.59\%. Kecamatan Rajeg terdiri dari 12 desa dan 1 kelurahan, dengan batas-batas wilayah sebelah Utara berbatasan dengan Kecamatan Mauk, sebelah Selatan berbatasan dengan Kecamatan Pasar Kemis (Desa Sindang Jaya), Sebelah Barat berbatasan dengan Kecamatan Kemiri dan Sebelah Timur berbatasan dengan Kecamatan Sepatan (Desa Sukadiri).

Alat yang digunakan adalah perangkat komputer yang dilengkapi dengan software ArcGIS 10.5, Google Earth Pro, Fragstats, dan Microsoft Office. Data yang digunakan adalah data sekunder. Data sekunder berupa studi kepustakaan, peta dan data tabular pendukung penelitian, hasil penelitian sebelumnya, perundangundangan yang berhubungan dengan topik penelitian.

Data sekunder diperoleh dari berbagai sumber baik instansi pemerintah, literatur maupun situs-situs penyedia data dan informasi. Jenis data sekunder yang digunakan adalah peta Rupa Bumi Indonesia (RBI) Kecamatan Rajeg dari Badan Informasi Geospasial (BIG) skala 1:25,000, citra Image Google Earth tahun 2005, 2012 dan 2018 Kecamatan Rajeg, peta status kepemilikan lahan tahun 2018 skala 1:5,000 dari Badan Pertanahan Nasional (BPN) Kabupaten Tangerang, dokumen dan peta Rencana Tata Ruang Wilayah (RTRW) Kabupaten Tangerang dan data penunjang lainnya. Penelitian ini terdiri dari beberapa tahapan analisis yakni: (1) menganalisis dinamika perubahan penggunaan lahan di Kecamatan Rajeg; dan (2) menganalisis pola spasial konversi lahan sawah di Kecamatan Rajeg.

Proses analisis diawali dengan melakukan interpretasi dan delineasi batas penggunaan lahan (Murtadho et al., 2018) dengan citra image google earth Kecamatan Rajeg tahun 2005, 2012 dan 2018. Tahapan dilakukan dengan menggunakan software ArcGIS 10.5 melalui pendekatan interpretasi data penginderaan jauh hingga menghasilkan klasifikasi peta penggunaan lahan. Citra yang diunduh dari Image Digital Google Earth merupakan sebuah citra yang bereksitensi Joint Photographic Experts Group (JPEG) yang selanjutnya dilakukan koreksi geometri agar sesuai dengan koordinat sesungguhnya dipermukaan bumi. Citra yang disajikan oleh digital globe dengan resolusi spasial cukup tinggi, tersaji secara bebas/tidak berbayar dan dapat diakses dengan mudah (Utami et al., 2018). Klasifikasi peta penggunaan lahan disesuaikan dengan kebutuhan analisis berdasarkan pedoman Standar Nasional Indonesia (SNI) 7645:2010 klasifikasi penutup lahan skala $1: 25,000$.

\section{Analisis Dinamika Perubahan Penggunaan Lahan Di Kecamatan Rajeg}

Analisis dinamika perubahan penggunaan lahan dilakukan dengan metode overlay antara peta penggunaan lahan tahun 2005 dengan tahun 2012, dan peta penggunaan lahan tahun 2012 dengan tahun 2018 (Indrayani et al., 2017; Widjayatnika et al., 2017). Tahapan pertama adalah penyamaan atau koreksi koordinat antara dua peta yang digunakan kemudian dilanjutkan dengan proses overlay untuk mendapatkan data perubahan penggunaan lahan antara dua titik tahun. Keluaran akhir dari tahapan ini berupa matrik perubahan penggunaan lahan dan peta perubahan penggunaan lahan (Kurnianty et al., 2015) di tiap periode. Peta dan data tabular dari laju konversi penggunaan lahan di tiap periode akan digunakan pada proses analisis selanjutnya. 


\section{Analisis Pengaruh Pola Ruang Dan Status Kepemilikan Lahan Terhadap Konversi Penggunaan Lahan Di Kecamatan Rajeg}

Peruntukan ruang di Kecamatan Rajeg terbagi menjadi dua kawasan diantaranya kawasan pertanian yang sebagian besar diperuntukkan untuk pertanian lahan basah, dan kawasan hunian kepadatan sedang (RTRW Kabupaten Tangerang Tahun 2011-2031). Informasi mengenai pola ruang dan status kepemilikan lahan penting diketahui untuk menjaga kesesuaian dalam pemanfaatan lahannyaKetidaksesuaian dapat menimbulkan fenomena alih fungsi lahan (Wulandari, 2018) terutama pada lahan-lahan pertanian yang terkonversi menjadi lahan non pertanian. Tiap penggunaan lahan dilekati oleh status kepemilikan lahan (Basumi, 2003) meskipun tidak semua jenis penggunaan lahan tertera jelas status lahannya.

Berdasarkan Undang-Undang Pokok Agraria No 5 Tahun 1960, nomenklatur status kepemilikan lahan yang diatur oleh BPN mencakup 5 hak diantaranya hak milik, hak guna usaha, hak guna bangunan, hak pakai, dan hak pengelolaan. Sedangkan status kepemilikan lahan di Kecamatan Rajeg terbagi menjadi lima jenis dianataranya Hak Guna Bangunan (HGB) 8.35\%, Hak Milik 18.95\%, Hak Pakai 0.14\%, Hak Wakaf $0.04 \%$, Unregistered $72.53 \%$.

Pada tahapan ini peta dinamika penggunaan lahan yang dihasilkan pada analisis sebelumnya dilakukan overlay dengan peta pola ruang RTRW Kabupaten Tangerang tahun 2011-2031 dan peta status kepemilikan lahan di Kecamatan Rajeg. Proses selanjutnya adalah mengeliminasi jenis konversi lahan pada kawasan hunian kepadatan sedang dengan asumsi perubahan dari penggunaan lahan pertanian ke non pertanian pada kawasan tersebut bukan termasuk bentuk ancaman konversi karena telah sesuai dengan peruntukan ruangan. Output yang dihasilkan berupa peta sebaran dan luasan jenis konversi penggunaan lahan sawah di kawasan pertanian dengan keterkaitan status kepemilikan lahannya (Budiman, 2009).

\section{Analisis Pola Spasial Konversi Lahan Sawah}

Pada penelitian ini, pola spasial konversi lahan sawah dianalisis menggunakan spatial metric sebagai metode untuk mengetahui karakteristik pola spasial dan struktur geometri dari tiap jenis konversi lahan sawah. Spatial metric biasa disebut dengan analisis Landscape Metric (LMs) (Wulandari, 2018; Jatayu, 2020). Landscape Metric (LMs) didefinisikan sebagai indeks kuantitatif untuk menggambarkan struktur dan pola karakteristik dari suatu lanskap yang diamati (McGarigal \& Marks, 1995). Penelitian Frank (2012) menggunakan pendekatan LMs untuk memperhitungkan pola spasial dan struktur lanskap terhadap pengelolaan ekosistem. Dalam studi pewilayahan, metrik spasial biasanya digunakan untuk mengukur bentuk geometri perkotaan di wilayah tertentu (Debbage, 2012; Magidi, 2018). Bentuk perkotaan bukan hanya aspek visual suatu wilayah itu juga mempengaruhi dan dipengaruhi oleh berbagai faktor lainnya di suatu daerah berkembang (Jatayu, 2020).

Analisis pola spasial menggunakan landscape metrics index yang dibagi dalam tiga kategori yakni area and edge metrics, shape metrics dan spatial-distribution metrics. Indikator area and edge matrics adalah untuk mengukur komposisi lanskap. Area dari patch menjadi informasi dasar dari setiap mozaik lanskap dan juga menjadi dasar informasi untuk indeks level patch, class dan landscape. Pada penelitian ini analisis pola spasial dilakukan pada level class. Adapun indeks LMs yang digunakan telah disajikan pada Tabel 1. 
Tabel 1. Indeks Landscape Metric

\begin{tabular}{|c|c|c|}
\hline $\begin{array}{l}\text { Indeks } \\
\text { Landscape } \\
\text { Metric }\end{array}$ & Unit & Definisi \\
\hline $\begin{array}{l}\text { CLASS } \quad O F \\
\text { AREA (CA) }\end{array}$ & $\sum_{j=1}^{n} a \mathrm{ij}\left(\frac{1}{10.000}\right)$ & $\begin{array}{l}\mathrm{CA}=\text { Jumlah luas wilayah dari seluruh patch yang berada } \\
\text { dalam kelas yang sama(ha); Aij = area }(\mathrm{m} 2) \text { dari patch } \mathrm{ij} .\end{array}$ \\
\hline $\begin{array}{l}\text { PERCENT OF } \\
\text { LANDSCAPE } \\
(P L A N D)\end{array}$ & $P L A N D=\frac{\sum_{j=1}^{n} a_{i j}}{A}(100)$ & $\begin{array}{l}\text { Metrik PLAND dapat merepresentasikan perbandingan } \\
\text { pada landscape yang diamati. }\end{array}$ \\
\hline $\begin{array}{l}\text { NUMBER OF } \\
P A T C H(N P)\end{array}$ & $\mathrm{NP}=\mathrm{n}_{\mathrm{i}}$ & $\begin{array}{l}\mathrm{NP}=\text { Jumlah patch yang sesuai pada kelas yang sama. NP } \\
\text { dapat menunjukkan keheterogenan suatu bentukan } \\
\text { landscape di studi area }\end{array}$ \\
\hline $\begin{array}{l}\text { LARGEST } \\
\text { PATCH INDEX } \\
(L P I)\end{array}$ & $\begin{array}{c}n \\
\max (a i j) \\
\mathrm{j}=1 \\
\frac{A}{A}(100)\end{array}$ & $\begin{array}{l}\text { LPI sama dengan persentase dari patch terbesar di suatu } \\
\text { kelas terhadap lanskap secara keseluruhan. }\end{array}$ \\
\hline $\begin{array}{l}\text { LARGEST } \\
\text { SHAPE INDEX } \\
(\text { LSI) }\end{array}$ & $\frac{25 \sum_{K=1}^{M} e * i k}{\sqrt{A}}$ & $\begin{array}{l}\text { Bentuk geometri pada suatu lanskap dengan } \\
\text { mengkuantifikasi jumlah tepi yang ada pada area lanskap. }\end{array}$ \\
\hline COHESION & {$\left[1-\frac{\sum_{j=1}^{n} p_{i j}}{\sum_{j=1}^{n} p_{i j} \sqrt{a_{i j}}}\right]\left[1-\frac{1}{\sqrt{z}}\right]^{-1}$} & $\begin{array}{l}\text { Nilai } C O H E S I O N \text { mendekati } 0=\text { dalam satu class terdapat } \\
\text { banyak patch yang tidak terkoneksi atau terpisah-pisah. } \\
\text { Semakin tinggi nilai } C O H E S I O N=\text { patch-patch dalam satu } \\
\text { class tersebut saling terhubung satu sama lain }\end{array}$ \\
\hline$M E S H$ & $\frac{\sum_{j=1}^{n} a_{i j}^{2}}{A}(100)$ & $\begin{array}{l}\text { Metrik MESH menunjukkan indeks fragmentasi class, } \\
\text { dimana semakin tinggi nilai } M E S H \text { maka suatu class } \\
\text { tersebut akan semakin terkumpul/tidak terfragmentasi. }\end{array}$ \\
\hline SPLIT & $\frac{A^{2}}{\sum_{j=1}^{n} a_{i j}^{2}}$ & $\begin{array}{l}\text { Dimana } \mathrm{A}^{2} \text { adalah nilai kuadrat dari luas suatu landscape } \\
\text { yang diamati sedangkan } \Sigma \mathrm{a}_{\mathrm{ij}}{ }^{2} \text { adalah total luas }\end{array}$ \\
\hline $\begin{array}{l}\text { Aggregation } \\
\text { index }(A I)\end{array}$ & $A I=\left[\sum_{1=1}^{m}\left(\frac{g_{i i}}{\max \rightarrow g_{i i}}\right) P_{i}\right](100)$ & $\begin{array}{l}\text { Aggregation index }(\mathrm{AI}) \text { dihitung dari matriks } \\
\text { ketetanggaan, yang menunjukkan frekuensi pasangan jenis } \\
\text { patch yang berbeda (termasuk kedekatan serupa di antara } \\
\text { jenis patch yang sama) yang berdampingan di peta. } \\
\text { Dimana: } \mathrm{g}_{\mathrm{ii}} \text { adalah jumlah kedekatan serupa (gabungan) } \\
\text { antara piksel dengan tipe patch (kelas) } \mathrm{i} \text { berdasarkan } \\
\text { metode penghitungan tunggal; max- } \mathrm{g}_{\mathrm{ii}} \text { adalah jumlah } \\
\text { maksimum kedekatan serupa (gabungan) antara piksel } \\
\text { dengan tipe patch (kelas) } \mathrm{i} \text { berdasarkan metode } \\
\text { penghitungan tunggal; dan Pi = proporsi lanskap yang } \\
\text { terdiri dari tipe patch (kelas) } \mathrm{i} \text {. }\end{array}$ \\
\hline $\begin{array}{l}\text { Contiguity index } \\
\text { (CONTIG) }\end{array}$ & $\operatorname{CONTIG}=\frac{\left[\frac{\sum_{r=1}^{n} c_{i j r}}{a_{i j}}\right]-1}{v-1}(100)$ & $\begin{array}{l}\text { Contiguity Index memiliki nilai berkisar antara 0-1 dimana } \\
\text { nilai } 0 \text { menunjukkan bahwa masing-masing kelas } \\
\text { penggunaan lahan terdiri dari patch-patch yang tidak } \\
\text { berdekatan atau tersebar dalam satu landscape. } \\
\text { Dimana: } \mathrm{c}_{\mathrm{ijr}} \text { adalah nilai ketetanggaan pixel } \mathrm{r} \text { dalam patch } \\
\text { ij (ketetanggaan dilihat berdasarkan kelas yang sama). } \mathrm{v} \\
\text { adalah jumlah nilai pixel tetangga dalam template } 3 \times 3 . \mathrm{a}_{\mathrm{ij}} \\
\text { adalah jumlah pixel dalam patch } \mathrm{ij} \text {. }\end{array}$ \\
\hline
\end{tabular}




\section{HASIL DAN PEMBAHASAN}

Tahun 2018 penggunaan lahan di Kecamatan Rajeg didominasi oleh lahan sawah yakni seluas $2,557.51$ ha atau $54.12 \%$, permukiman sebesar $1,467.47$ ha atau $31.5 \%$ dan tegalan 492.83 atau $10.43 \%$ [Tabel 2].
Lahan sawah dan kebun campuran terus terjadi pengurangan luasan di setiap periode tahunnya sedangkan permukiman, tegalan dan penggunaan lahan lainya terjadi penambahan luasan. Peta penggunaan lahan tahun 2005, 2012 dan 2018 disajikan pada Gambar 2.

Tabel 2. Luas tiap jenis penggunaan lahan di Kecamatan Rajeg pada Tahun 2005, 2012, dan 2018

\begin{tabular}{llrrr}
\hline \multirow{2}{*}{ No. } & \multirow{2}{*}{ Penggunaan lahan } & \multicolumn{2}{c}{ Periode tahun (ha) } & \multicolumn{2}{c}{ Tahun 2012 } & \multicolumn{1}{c}{ Tahun 2018 } \\
\cline { 3 - 5 } & & 42.44 & 29.43 & 50.36 \\
\hline 1 & Badan air & 113.00 & 73.75 & 71.76 \\
2 & Kebun campuran & 14.26 & 49.86 & 48.78 \\
3 & Lahan terbuka & 917.32 & $1,114.22$ & $1,467.47$ \\
4 & Permukiman & $3,327.24$ & $3,107.54$ & $2,557.51$ \\
5 & Sawah & 28.08 & 14.48 & 37.02 \\
6 & Semak & 283.38 & 336.44 & 492.83 \\
7 & Tegalan & $4,725.72$ & $4,727.72$ & $4,727.72$ \\
\hline
\end{tabular}

\section{Dinamika Konversi Penggunaan Lahan di Kecamatan Rajeg}

Menurut Mendoza et al. (2011) perubahan tutupan lahan dan penggunaan lahan secara langsung berkaitan dengan ketahanan pangan, jaminan kesehatan, manusia, urbanisasi, hilangnya keanekaragaman hayati, migrasi, pelestarian lingkungan, kualitas air dan tanah, dan air limpasan dan tingkat sedimentasi, dan proses lainnya.

Proses suburbanisasi wilayah Metropolitan DKI Jakarta terus meluas di wilayah-wilayah pinggirannya (Pribadi et al., 2018), seperti yang telah dijelaskan pada Rustiadi et al. (2003), bahwa perluasan tersebut disebabkan oleh meluasnya perkembangan kawasan permukiman di wilayah pinggiran kota dan proses konversi lahan yang merupakan lahan-lahan produktif.

Tabel 3 menunjukkan luas total konversi penggunaan lahan pada periode tahun 20052018 sebesar 1,621.94 ha atau $34.32 \%$ dari luas wilayah kecamatan Rajeg. Sedangkan penggunaan lahan seperti badan air, lahan terbuka, permukiman, semak dan tegalan mengalami peningkatan luasan. Permukiman mengalami peningkatan luasan tertinggi sebesar 550.15 ha atau $33.92 \%$, diikuti oleh tegalan seluas 209.45 ha atau $12.91 \%$ dari total luas konversi yang terjadi.

Tabel 3 Luas konversi lahan di Kecamatan Rajeg di tiap periode

\begin{tabular}{|c|c|c|c|c|c|}
\hline \multirow{2}{*}{ No. } & \multirow{2}{*}{ Penggunaan lahan } & \multicolumn{2}{|l|}{ Periode tahun (ha) } & \multicolumn{2}{|l|}{ Konversi area } \\
\hline & & $2005-2012$ & $2012-2018$ & ha & $\%$ \\
\hline 1 & Badan air & -13.02 & 20.93 & 7.92 & 0.49 \\
\hline 2 & Kebun campuran & -39.25 & -1.99 & -41.24 & 2.54 \\
\hline 3 & Lahan terbuka & 35.60 & -1.08 & 34.52 & 2.13 \\
\hline 4 & Permukiman & 196.90 & 353.25 & 550.15 & 33.92 \\
\hline 5 & Sawah & -219.70 & -550.04 & -769.73 & 47.46 \\
\hline 6 & Semak & -13.60 & 22.54 & 8.94 & 0.55 \\
\hline 7 & Tegalan & 53.06 & 156.39 & 209.45 & 12.91 \\
\hline & Total & & & 1621.94 & 100.00 \\
\hline
\end{tabular}

Keterangan: angka positif = penambahan luasan; angka negatif $=$ penurunan luasan

Peningkatan tersebut diikuti dengan penurunan luasan pada penggunaan lahan lainnya. Penggunaan lahan sawah terjadi penurunan luasan tertinggi sebesar 769.73 ha atau $47.46 \%$, diikuti penggunaan lahan kebun campuran sebesar 41.24 ha atau $2.54 \%$. Gambar 3 menunjukkan grafik tren konversi penggunaan lahan di Kecamatan Rajeg. 


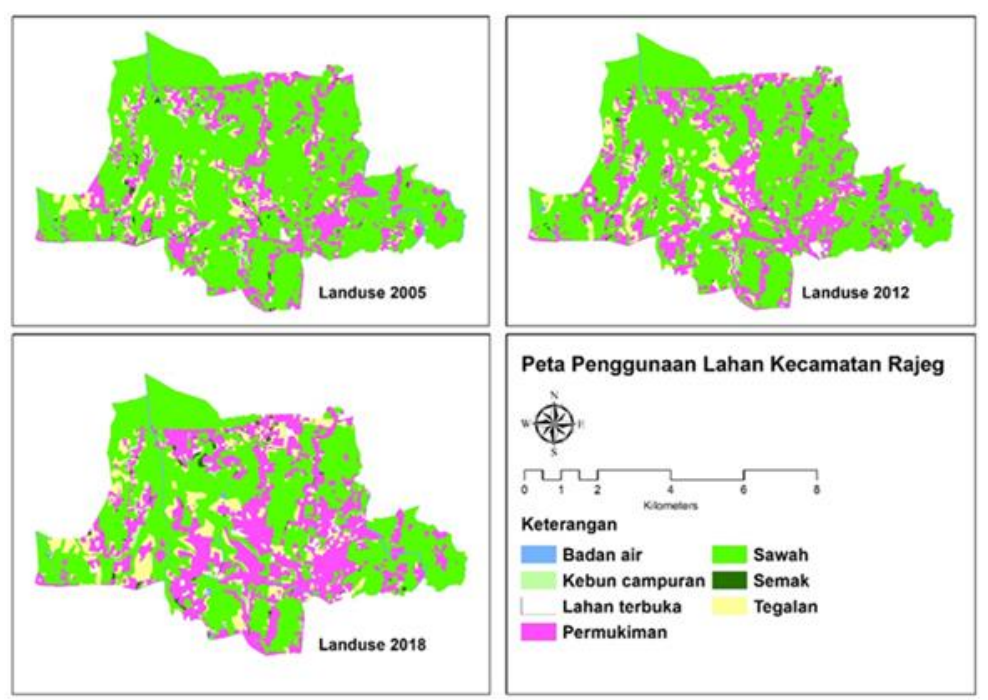

Gambar 2. Peta penggunaan lahan tahun 2005, 2012 dan 2018

Rustiadi et al. (2003) menyatakan salah satu dampak proses suburbanisasi yaitu meluasnya perkembangan kawasan permukiman di wilayah pinggiran kota dan proses konversi lahannya terjadi pada lahanlahan produktif. Pada penelitian ini, berkurangnya luasan lahan pertanian diakibatkan terjadi proses transformasi dari lahan pertanian ke non pertanian salah satunya menjadi permukiman (Bryon \& Lesslie, 2008; Sitorus, 2009).

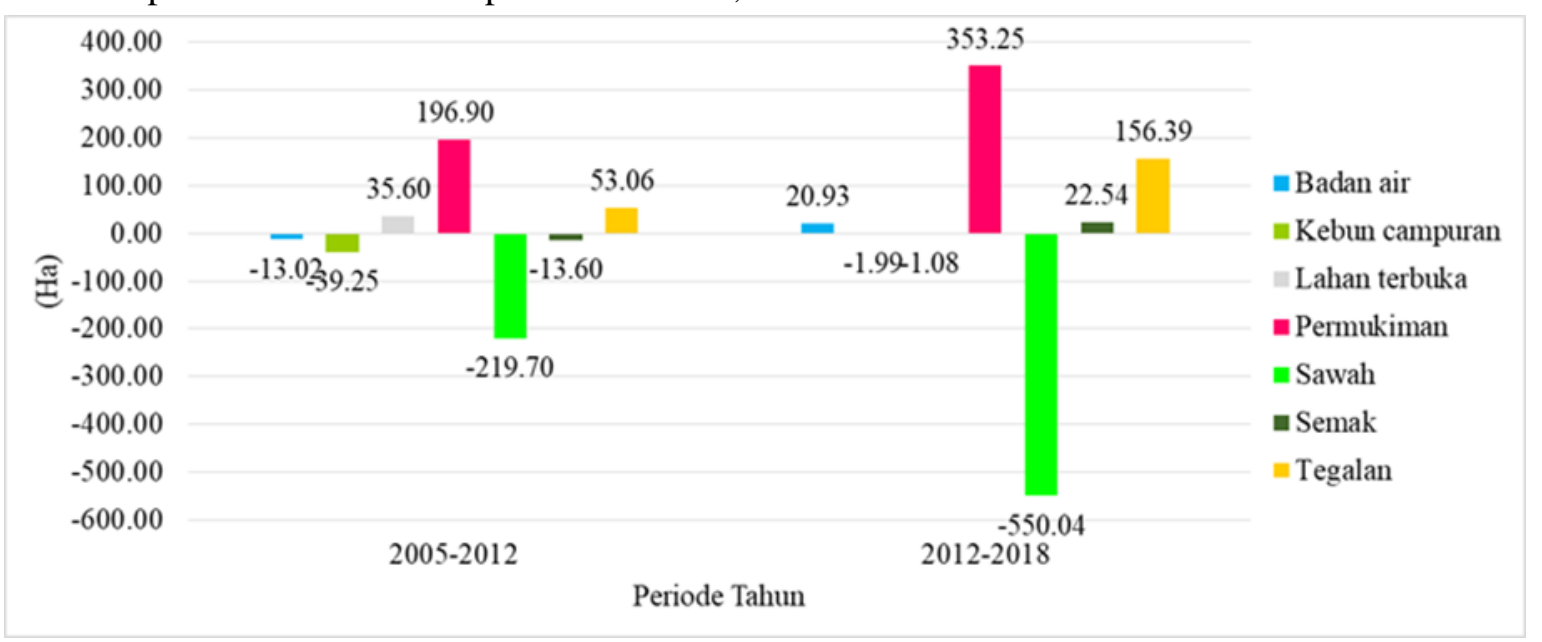

Gambar 3. Grafik tren konversi penggunaan lahan di Kecamatan Rajeg

Matriks transisi konversi penggunaan lahan periode tahun 2005-2018 di Kecamatan Rajeg disajikan pada Tabel 3. Berdasarkan Tabel tersebut, semua penggunaan lahan telah mengalami konversi. Konversi penggunaan lahan menjadi permukiman merupakan tertinggi yakni seluas 681.29 ha atau $49.99 \%$ diikuti penggunaan lahan tegalan sebesar 385.21 ha atau $28.27 \%$ dari total konversi yang terjadi. Menurut Handayani (2016) Keberadaan penggunaan lahan semakin kompetitif sehingga membuat lahan-lahan pertanian akan kalah dengan lahan non pertanian.

Rustiadi et al. (2007) menyatakan bahwa salah satu faktor yang mengakibatkan terjadinya konversi pada penggunaan lahan pertanian terutama lahan sawah adalah nilai tanah (land rent) lahan pertanian yang relatif rendah jika dibandingkan dengan land rent penggunaan lahan non pertanian. Perubahan penggunaan lahan secara langsung berkaitan dengan ketahanan pangan, manusia, urbanisasi, 
hilangnya keanekaragaman hayati dan lain sebagainya (Mendoza et al., 2011), namun faktor sosial ekonomi memicu para pengembang mengalihfungsikan lahan pertanian menjadi kawasan perumahan dengan nilai tambah (aksesibilitas), tak terkecuali warga dengan hak kepemilikannya.

Tabel 4. Matriks transisi konversi penggunaan lahan periode tahun 2005-2018

\begin{tabular}{|c|c|c|c|c|c|c|c|c|}
\hline \multirow{2}{*}{$\begin{array}{l}\text { PL } \\
2005\end{array}$} & \multicolumn{7}{|c|}{ PL $2018(\mathrm{Ha})$} & \multirow{2}{*}{$\begin{array}{l}\text { Jumlah } \\
\text { konversi }\end{array}$} \\
\hline & BA & $\mathrm{KC}$ & LT & PMK & SWH & SMK & TGL & \\
\hline $\mathrm{BA}$ & & 0.58 & 0.02 & 6.16 & 15.39 & 0.05 & 1.61 & 23.81 \\
\hline $\mathrm{KC}$ & 0.17 & & 0.12 & 66.37 & 12.15 & 8.16 & 10.39 & 97.34 \\
\hline $\mathrm{LT}$ & & 0.79 & & 6.79 & 4.45 & & 2.24 & 14.26 \\
\hline PMK & 3.66 & 17.88 & 2.93 & & 42.62 & 8.79 & 55.25 & 131.14 \\
\hline SWH & 26.48 & 20.57 & 39.76 & 479.25 & & 14.67 & 312.61 & 893.34 \\
\hline SMK & 0.59 & 3.21 & 0.16 & 15.44 & 4.55 & & 3.13 & 27.08 \\
\hline TGL & 0.88 & 13.07 & 5.79 & 107.30 & 44.37 & 4.34 & & 175.75 \\
\hline Total & 31.78 & 56.10 & 48.78 & 681.29 & 123.53 & 36.02 & 385.21 & $1,362.71$ \\
\hline$\%$ & 2.33 & 4.12 & 3.58 & 49.99 & 9.07 & 2.64 & 28.27 & 100.00 \\
\hline
\end{tabular}

Keterangan: $\mathrm{BA}=$ Badan air; $\mathrm{KC}=$ Kebun campuran; $\mathrm{LT}=$ Lahan terbuka; $\mathrm{PMK}=$ Pemukiman; $\mathrm{SWH}=\mathrm{Sawah}$; $\mathrm{SMK}=$ Semak; TGL=Tegalan

\section{Pola Ruang, Status Kepemilikan Lahan dan Konversi Penggunaan Lahan}

Peruntukan ruang di Kecamatan Rajeg diatur oleh Peraturan Daerah No 13 Tahun 2011-2031 Tentang Rencana Tata Ruang Wilayah Kabupaten Tangerang. Pada peruntukannya wilayah kecamatan Rajeg dialokasikan sebagai kawasan budidaya yang terbagi menjadi dua kawasan yaitu kawasan pertanian dan kawasan hunian kepadatan sedang dengan persentase masing-masing sebesar $52.56 \%$ dan $47.44 \%$. Kawasan pertanian sebagian besar dialokasikan untuk pertanian lahan basah (lahan sawah).

Pada kenyataan aktual pemanfaatan ruang ditemukan fenomena inkonsistensi antara peruntukan ruang dengan pemanfaatan ruangnya. Isa (2008) menjelaskan bahwa implementasi penataan ruang merupakan penerapan kepentingan publik terhadap tanah yang dilekati hak, sehingga diperlukan strategi penyelenggaraan pengaturan penguasaan, pemilikan, penggunaan dan pemanfaatan tanah serta pengawasan kelembagaan dalam proses implementasi di lapangan.

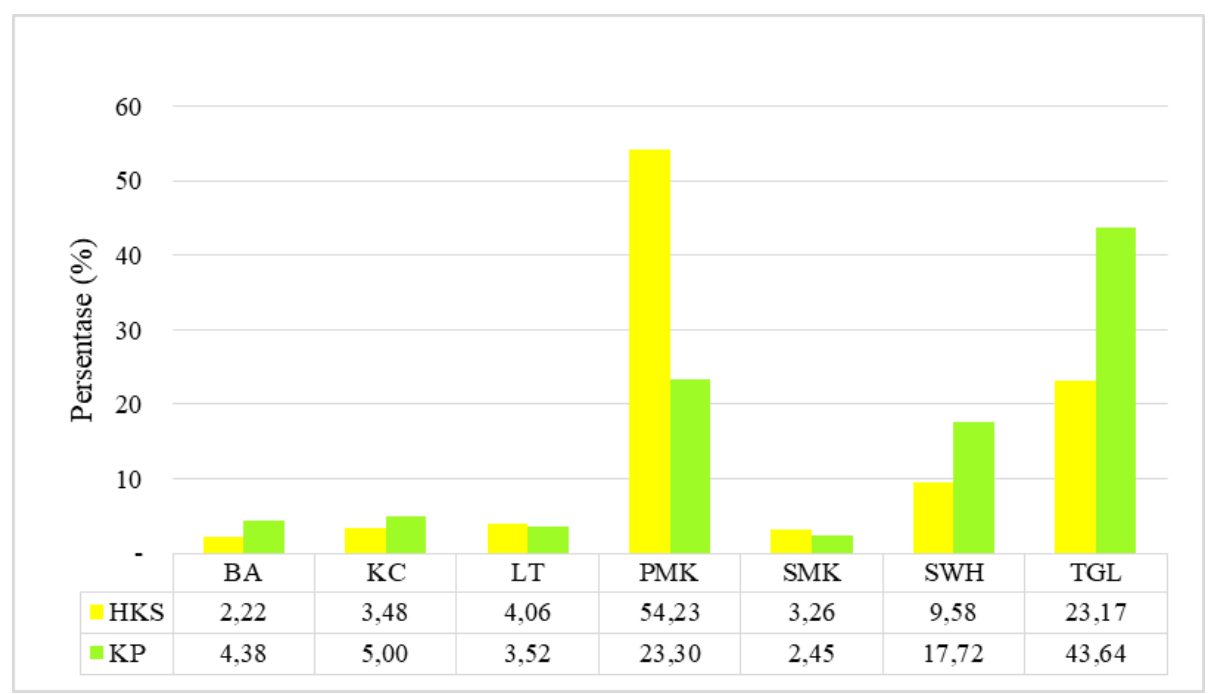

Keterangan: $\mathrm{BA}=$ Badan air; $\mathrm{KC}=$ Kebun campuran; $\mathrm{LT}=\mathrm{Lahan}$ terbuka; $\mathrm{PMK}=$ Pemukiman; SWH=Sawah; SMK=Semak; TGL=Tegalan; HKS=Hunian Kepadatan Sedang; KP=Kawasan Pertanian

Gambar 4. Grafik konversi penggunaan lahan setiap kawasan periode 2012-2018 
Gambar 4 menyajikan data konversi penggunaan lahan periode tahun 2012-2018 di overlay dengan peta pola ruang RTRW kabupaten Tangerang tahun 2011-2031 untuk melihat sejauh mana implementasi kebijakan pemerintah tentang pengawasan dan pengendalian pemanfaatan ruang terhadap konversi penggunaan lahan yang terjadi. Hasil analisis menunjukan penetapan status kawasan belum efektif untuk menahan laju konversi penggunaan lahan. Sosialisasi dan pendekatanpendaekatan secara persuasif kepada pihakpihak menjadi hal yang penting dalam meningkatkan pemahaman tentang pemanfaatan ruang.

Berdasarkan grafik tersebut terdapat penambahan luasan pada permukiman (PMK) di kawasan hunian sedang (HKS) dan kawasan pertanian (KP) berturut-turut sebesar 466.28 ha atau $54.23 \%$ dan 83.84 ha atau $23.30 \%$ dari total konversi. Konversi penggunaan lahan menjadi permukiman (PMK) pada kawasan hunian kepadatan sedang (HKS) sesungguhnya telah sejalan dengan rencana RTRW namun perlu dikendalikan dan diatur agar tidak menyebabkan overload pada kawasan tersebut dan juga dapat memudahkan dalam penyediaan sarana prasarana dan utilitas kawasan untuk mencapai kawasan hunian yang layak, sehat, aman dan teratur.

Sedangkan konversi penggunaan lahan ke permukiman (PMK) pada kawasan pertanian (KP) menjadi hal yang perlu diperhatikan mengingat status kawasannya sehingga perlu adanya tindakan tegas dari pemerintah daerah. Lahan pertanian khususnya pertanian pangan produktif yang ada di kawasan pertanian (KP) agar selalu dipertahankan dan ditetapkan sebagai Lahan Pertanian Pangan Berkelanjutan (LP2B) sebagai landasan hukum perlindungannya. Menurut Pribadi et al. (2018), perkembangan pembangunan permukiman dan jaringan jalan di sekitar kawasan metropolitan DKI Jakarta sudah menghubungkan lahan pertanian ke pasar perkotaan, namun kondisi ini tidak akan tercapai maksimal jika kawasan perkotaan terus meluas dan menggusur lahan-lahan pertanian di pinggiran kota. Namun saat ini, pemerintah daerah dan nasional mengambil langkah untuk membatasi perluasan perkotaan. Hasil proses overlay antara peta pola ruang dan peta penggunaan lahan disajikan pada Gambar 5.

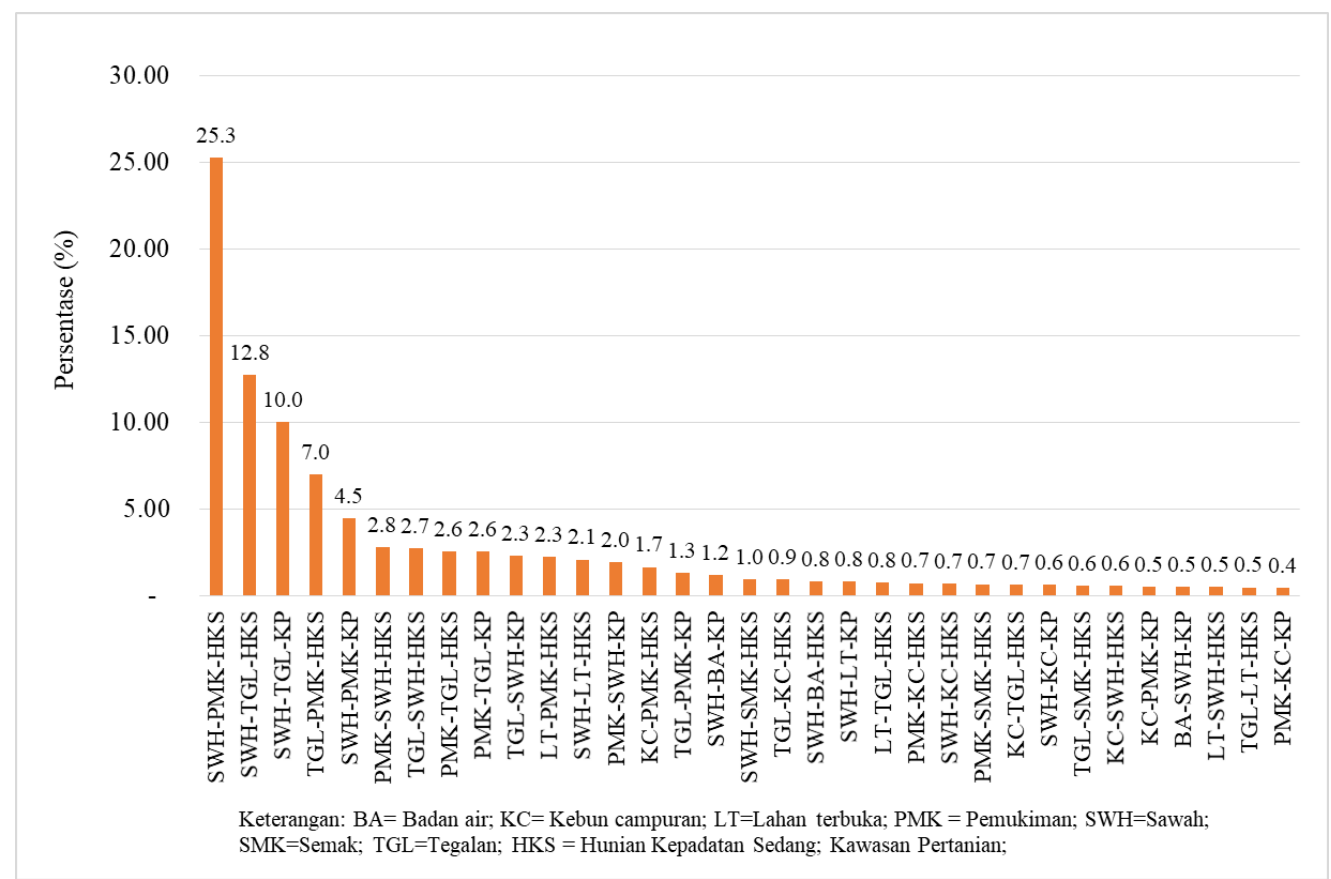

Gambar 5. Tipe konversi penggunaan lahan pada periode tahun 2012-2018 
Persentase jenis konversi terbesar diantaranya jenis konversi penggunaan lahan sawah (SWH) menjadi permukiman (PMK) di kawasan hunian kepadatan sedang (HKS) sebesar 291.19 ha atau $25.30 \%$, diikuti sawah (SWH) menjadi tegalan (TGL) pada kawasan hunian kepadatan sedang (HKS) sebesar 146.92 ha atau $12.76 \%$, sawah (SWH) menjadi tegalan (TGL) di kawasan pertanian (KP) sebesar 155.44 ha atau $10.03 \%$, tegalan (TGL) menjadi permukiman (PMK) di kawasan hunian kepadatan sedang (HKS) sebesar 80.90 ha atau $7.03 \%$ dan sawah menjadi permukiman sebesar 51.61 ha atau $4.48 \%$ dari total luas konversi penggunaan lahan.

Menurut Ruswandi (2007), konversi lahan pertanian terjadi sebagai konsekuensi logis dari perkembangan wilayah, namun konversi lahan pertanian seringkali menimbulkan dampak negatif terutama dalam konteks ketahanan pangan dan kondisi sosial ekonomi petani. Kebijakan rencana tata ruang wilayah kabupaten Tangerang 2011-2031 dalam mengakomodasi lahan-lahan pertanian sawah yang produktif dapat ditetapkan sebagai Lahan Pertanian Pangan Berkelanjutan (LP2B) sebagai landasan hukum yang kuat untuk mendukung ketahanan pangan lokal maupun nasional, mempertahankan luas bahan baku sawah, dan penyediaan lapangan kerja.

Pada fenomena perubahan lahan pertanian (lahan sawah) menjadi permukiman penduduk yang erat kaitannya dengan kepemilikan lahan perseorangan dan organisasi (Trimarmanti, 2014). Faktor sosial-ekonomi memicu para pengembang mengkonversi lahan pertanian menjadi kawasan perumahan dengan nilai tambah aksesibilitas tak terkecuali pada warga dengan hak kepemilikannya (Mendoza $e t$ al., 2011).

Kecamatan Rajeg memiliki 4 jenis status kepemilikan lahan diantaranya hak guna bangunan (HGB), hak milik (HM), hak pakai (HP) dan hak wakaf (HW). Hasil overlay antara peta konversi penggunaan lahan tahun 20122018 dengan peta status kepemilikan lahan tahun 2018 menunjukkan bahwa sebesar 64.79\% konversi lahan terjadi pada lahan-lahan dengan status Unregistered (UR), diikuti dengan status hak guna bangunan (HGB) sebesar $19.60 \%$ dan status hak milik (HM) sebesar $15.45 \%$ dari total luas konversi penggunaan lahan di Kecamatan Rajeg [Gambar 6]. Status lahan berupa UR merupakan lahan-lahan milik negara atau lahan-lahan yang belum terdaftar sehingga tidak memiliki sertifikat atas tanah tersebut. Penggunaan lahan yang dilekati dengan status lahan UR berpeluang besar untuk mengalami fenomena konversi lahan (Wulandari, 2018; Basumi, 2003) karena tidak ada peraturan jelas mengenai hak dan kewajiban akan lahan tersebut, sehingga lahan tersebut akan masuk dalam kategori open access yang memungkinkan masuknya berbagai hak atau kepentingan (Basumi, 2003).

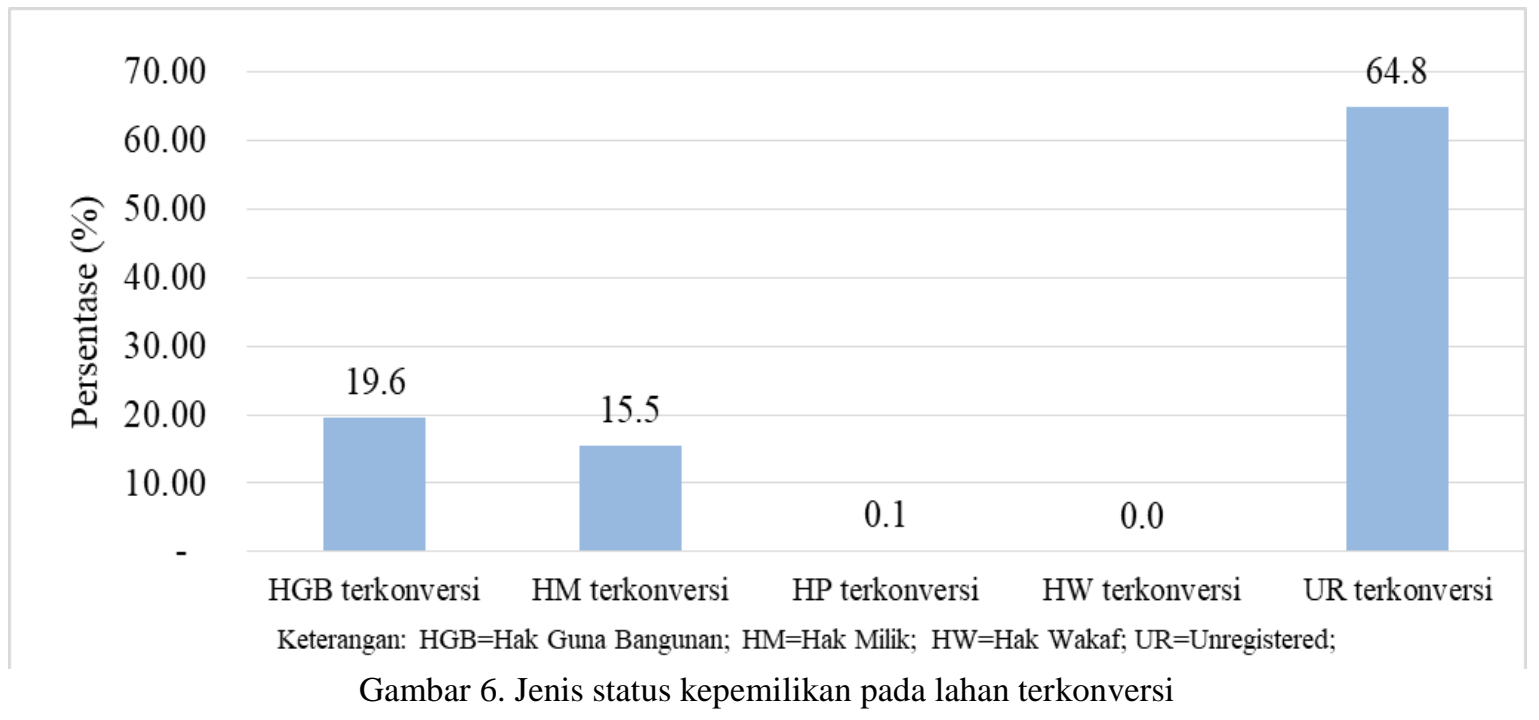


Badan Pertanahan Nasional memiliki fungsi untuk menyelesaikan konflik terkait sengketa tanah dan tanah belum terdaftar. Pada kenyataannya, tanah belum terdaftar tidak hanya terdapat di wilayah perdesaan tetapi juga banyak ditemukan di masyarakat perkotaan, hal ini menunjukkan bahwa masih banyak masyarakat yang merasa nyaman tinggal ataupun menguasai tanah belum terdaftar yang hanya dengan bukti girik, letter, petok, dan rincik. Deininger et al. (2011) menyatakan bahwa lahan yang sudah memiliki sertifikat cenderung memiliki tingkat keamanan tenurial yang tinggi, investasi tanah dan partisipasi di pasar tanah. Selain itu tanah yang sudah terdaftar dan memiliki sertifikat secara potensial dapat meningkatkan nilai tanah, meningkatkan kondisi sosial ekonomi dan kesejahteraan masyarakat pemilik tanah (Mardiana et al., 2016) serta dapat mengurangi konflik batas tanah (Holden et al., 2010).

\section{Pola Spatial Patch (Persil) Konversi Penggunaan Lahan Sawah}

Fenomena konversi perubahan penggunaan lahan sawah di kawasan pertanian perlu mendapatkan perhatian khusus agar pola konversi tersebut tidak bertambah luas dan mengancam ketersediaan pangan. Secara signifikan konversi lahan sawah dapat mempengaruhi ketersediaan pangan dan inventarisasi ketersediaan lahan sawah irigasi (Pribadi et al., 2016). Lanskap metriks (LMs) merupakan suatu metode untuk menggambarkan struktur dan pola karakteristik dari suatu area lanskap (Wulandari, 2018). Pada penelitian ini, metode tersebut digunakan untuk mengetahui struktur dan pola karakteristik dari tiap jenis konversi penggunaan lahan sawah yang dilakukan pada level class.

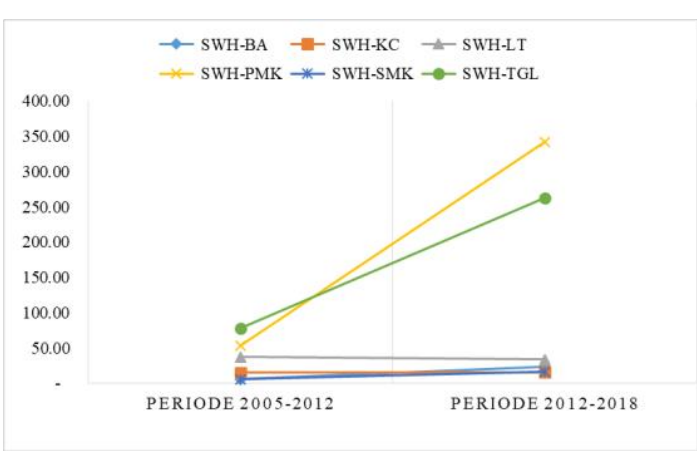

(a) Class of area (CA)

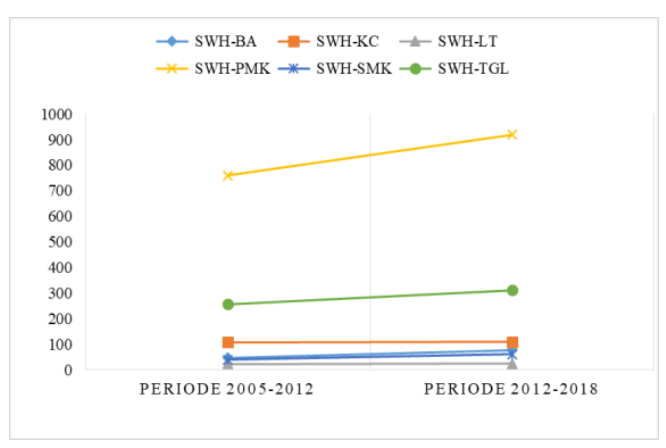

(b) Number of patch (NP)

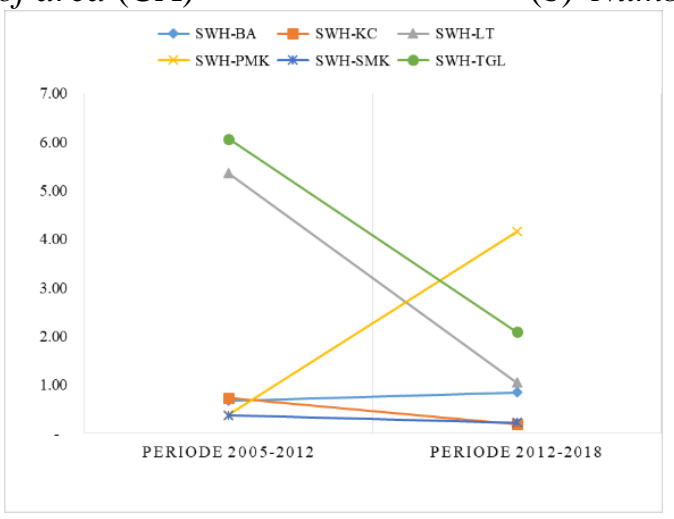

(c) Largest Patch Index (LPI)

Gambar 7. Grafik area and edge metrics 
Analisis pola spasial pada penelitian ini menggunakan indikator area and edge metrics disajikan pada gambar [Gambar 7]. Indeks CA [Gambar 7.a] dan NP [Gambar 7.b] tertinggi terdapat konversi lahan sawah menjadi permukiman, hal ini mengimplikasikan bahwa konversi lahan sawah menjadi permukiman di Kecamatan Rajeg terus meningkat dan semakin menunjukkan pengelompokan seperti yang terlihat pada grafik LPI [Gambar 7.c]. Indeks CA dan NP tertinggi setelah SWH-PMK adalah SWH-TGL, namun terus terjadi penurunan pada index LPI. Hal ini mengimplikasikan bahwa secara luasan konversi sawah menjadi tegalan cukup tinggi namun pola konversinya tersebar diseluruh area lanskap tidak menunjukkan pengelompokan.

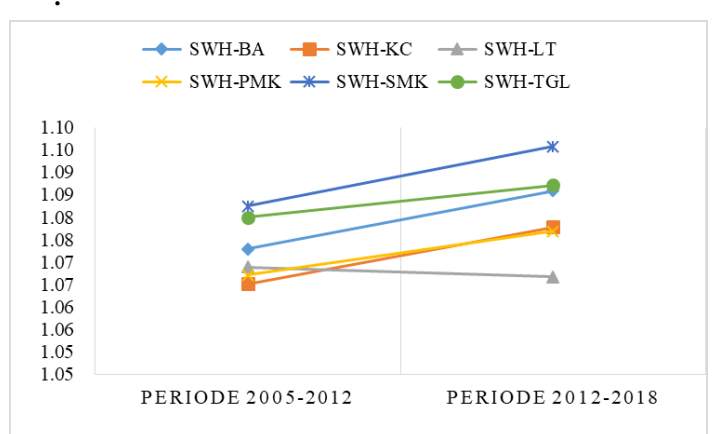

(a) FRAC

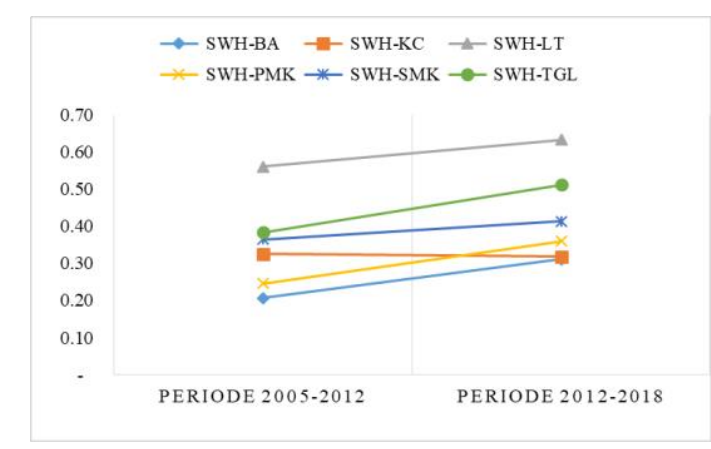

(b) CONTIG

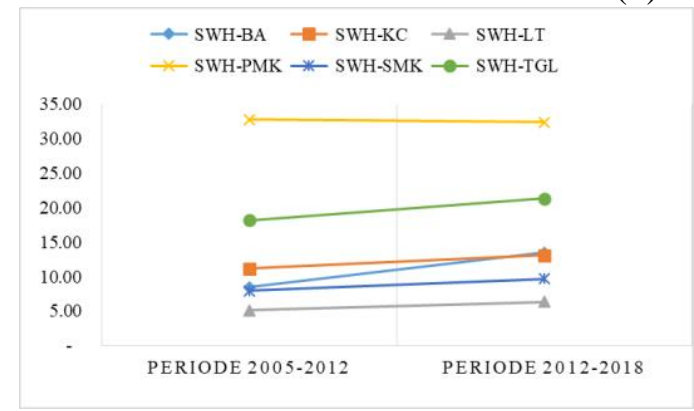

(c) LSI

Gambar 8. Grafik shape metrics

Indikator shape matrics disajikan pada Gambar 8. Semua konversi sawah menjadi penggunaan lainnya menunjukkan komplesitas pada bentuk geometrinya seperti yang ditunjukkan pada indeks FRAC [Gambar 8.a]. Selain itu patch-patchnya juga saling berdekatan antara konversi sawah satu dengan yang lainnya indeks CONTIG [Gambar 8.b]. Namun pada tipe konversi sawah menjadi permukiman (SWH-PMK) menunjukkan bentukan yang beragam seperti yang disajikan pada indeks LSI [Gambar 8.c]. Pola ini mengimplikasikan tipe konversi ini tersebar pada seluruh area lanskap dengan bentukannya masing-masing. Indikator Spatial-distribution metrics disajikan pada Gambar 9. Pada grafik indeks metrik MESH tipe konversi sawah menjadi permukiman

(SWH-PMK) menunjukkan peningkatan pada periode tahun 2012-2018 berikutnya ada tipe konversi sawah menjadi tegalan (SWH-TGL) juga menunjukkan peningkatan pada periode tersebut, hal ini mengindikasikan adanya penambahan patch pada tipe konversi tersebut dan terkumpul tidak terfragmentasi yang tersebar pada area-area tertentu [Gambar 9.a]. Pola ini juga didukung dengan nilai indeks metrik PD yang menunjukkan angka kepadatan pada tiap periodenya yang [Gambar 9.c] namun akan saling terhubung secara fisik dan lebih menunjukkan pengelompokan antara pacth satu sama lainnya seperti terlihat pada indeks metrik COHESION [Gambar 9.d] dan indeks metrik AI [Gambar 9.b]. Secara keseluruhan distribusi spasial pada tipe konversi sawah menjadi permukiman (SWH-PMK) masih sangat 
mendominasi. Karakteristik tersebut semakin menunjukkan pengelompokan dan kecenderungan akan saling berhubungan antara patch satu dan yang lainnya pada tipe konversi yang sama.

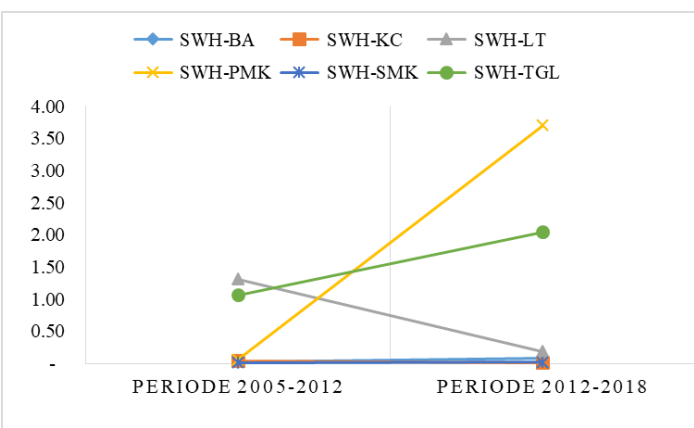

(a) MESH

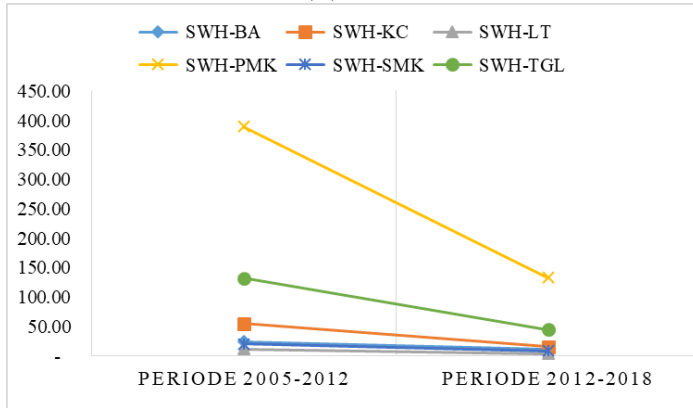

(c) PD

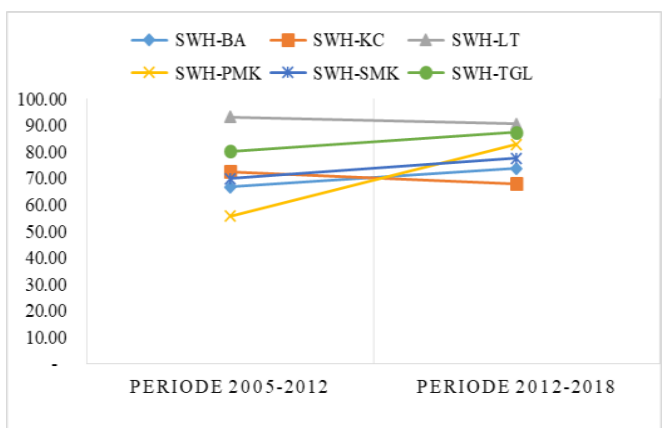

(b) $\mathrm{AI}$

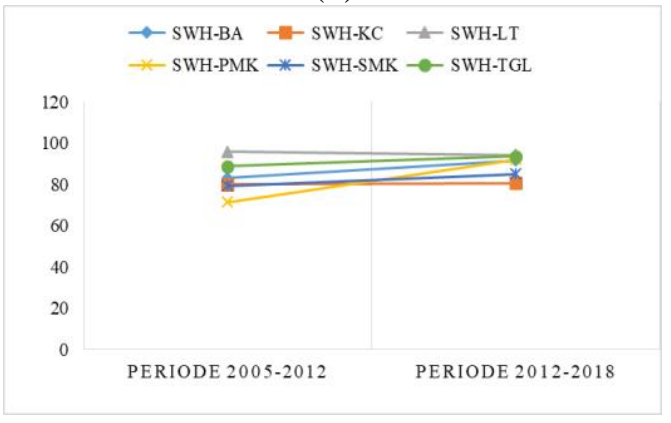

(d) COHESION

Gambar 9 Grafik Spatial-Distribution Metrics

Nilai indeks LMs menunjukkan bahwa jenis konversi terluas terjadi pada konversi penggunaan lahan sawah menjadi lahan terbangun yang berada di kawasan pertanian dengan jenis status kepemilikan lahannya unregistered. Karakteristik jenis konversi penggunaan lahan sawah tersebut memiliki bentuk keanekaragaman yang bersifat heterogen dengan sebaran kerapatan patchnya hampir menyebar diseluruh areal lanskap (persebaran lahan terbangun semakin menyeluruh). Lahan terbangun yang terbentuk pada jenis konversi ini cenderung bersifat masif dan berbentuk cluster.

Tindakan pengendalian pada jenis konversi penggunaan lahan sawah menjadi lahan terbangun di kawasan pertanian dengan status unregistered adalah meningkatkan pengawasan terhadap zonasi pemanfaatan ruang yang telah ditetapkan, menginvetarisasi lahanlahan yang belum terdaftar serta mempercepat proses sertifikasi, memberikan insentif pada lahan-lahan yang terus mempertahankan lahan untuk pertanian pangan, memperketat proses perizinan mendirikan bangunan, serta menetapkan status LP2B pada lahan sawah produktif.

\section{KESIMPULAN DAN SARAN}

\section{Kesimpulan}

1. Pola konversi penggunaan lahan di Kecamatan Rajeg terbagi menjadi dua yaitu lahan sawah berubah menjadi pertanian lahan kering, dan lahan sawah berubah menjadi lahan terbangun.

2. Konversi lahan sawah menjadi lahan terbangun di kawasan pertanian dengan status unregistered menjadi ancaman tertinggi dalam konversi lahan di Kecamatan Rajeg.

3. Karakteristik jenis konversi lahan sawah menjadi lahan terbangun di kawasan pertanian dengan status unregistered memiliki bentuk keanekaragaman yang bersifat heterogen dengan sebaran 
kerapatan patchnya hampir menyebar di seluruh areal lanskap (persebaran lahan terbangun semakin menyeluruh). Lahan terbangun yang terbentuk pada jenis konversi ini cenderung bersifat masif dan berbentuk cluster.

\section{Saran}

1. Perlu dilakukan penelitian terkait penerapan kebijakan LP2B pada lahanlahan pertanian pangan di Kecamatan Rajeg.

2. Perlu penelitian lebih lanjut mengenai metode pengendalian yang tepat dalam mengatasi lahan yang belum terdaftar dan belum tersertifikat.

\section{DAFTAR PUSTAKA}

Budiman, Y. (2009). Konversi Lahan Pertanian sebagai Strategi Adaptasi Petani (Kasus di RW 02 Desa Gunung Picung, Kecamatan Pamijahan, Kabupaten Bogor). Thesis. Institut Pertanian Bogor

Bryon \& Leslie. (2008). Spatial Methodologies for Integrating Social and Biophysical Data at a Regional of Catchment Scale. Land Use Change: Science, Policy and Management. London

[BPS] Badan Pusat Statistik Kabupaten Tangerang. (2001). Data Dalam Angka Kabupaten Tangerang Tahun 2001. Badan Pusat Statistik.

[BPS] Badan Pusat Statistik Kabupaten Tangerang. (2018). Data Dalam Angka Kabupaten Tangerang Tahun 2018. Badan Pusat Statistik.

Debbage, N. A. (2012). Quantifying Urban Form via Spatial Metrics and Its Climatic Implication. The University of Georgia: Athens, GA, USA.

Deininger, K., Ali, A. D., \& Alemu, T. (2011). Impacts of Land Certification on Tenure Security, Investment, and Land Market Participation: Evidence from Ethiopia. Land Economics, 87 (2), 312-334.
Effendi, P. M. L. \& Asmara, A. (2014). Dampak Pembangunan Infrastruktur Jalan dan Variabel Ekonomi Lain Terhadap Luas Sawah di Koridor Ekonomi Jawa. Jurnal Agribisnis Indonesia, 2 (1), 21-32.

Handayani, R. H. (2015). Penggunaan Lahan dan Nilai Sewa Lahan (Land Rent) Di Kawasan Puncak. Skripsi. Institut Pertanian Bogor.

Holden, S. T., Deininger, K., \& Ghebru, H. (2010). Impact of land registration and certification on land border conflicts in Ethiopia.

https://www.researchgate.net/publication/ 228433462_Impact_of_land_registration _and_certification_on_land_border_confl icts_in_Ethiopia. [5 November 2019].

Indrayani, P., Mitani, Y., Djamaluddin, I., \& Ikemi, H. (2017). A GIS Based Evaluation of Land Use Changes and Ecological Connectivity Index. Geoplanning: Journal of Geomatics and Planning, 4 (1), 9-18.

Isa, I. T. (2008). Penataan Ruang dalam Perspektif Pertanahan. Buletin Tata Ruang, Edisi Maret- April 2008.

Jatayu, A., Rustiadi, E. \& Pribadi, D. O. (2020). A Quantitative To Characterizing The Changes and Managing Urban Form For Sustaining The Suburb of a Mega-Urban Region: The Case of North Cianjur. Sustainability, $\quad 12, \quad 8085$; doi:10.3390/su12198085

Karenina, A., Rustiadi, E. \& Syaukat, Y. (2016). Strategi Perlindungan Lahan Pertanian Pangan Berkelanjutan di Kabupaten Tangerang. Jurnal Manajemen Pembangunan Daerah, 8 (2), https://doi.org/10.29244/jurnal_mpd.v8i2 .24827

Kurnianti, D. N., Rustiadi, E., \& Baskoro D. P. T. (2015). Land Use Projection for Spatial Plan Consistency in Jabodetabek. Indonesian Journal of Geography, 47 (2), 124-131. 
Magidi, J. \& Ahmed, F. (2018). Assessing Urban Sprawl Using Remote Sensing and Landscape Metrics: A Case Study of City of Tshwane, South Africa. Egypt. J. Remote Sens. Space Sci, 21, 241-253.

Mardiana, Y. S., Siregar, H., \& Juanda, B. (2016). Pengaruh Sertifikasi Tanah Terhadap Nilai Tanah dan Kondisi Ekonomi Masyarakat di Kabupaten Sukoharjo. Jurnal Aplikasi Bisnis dan Manajemen, 2 (3), 304-311.

Martini, S. (2011). Analisis Dampak Perubahan Penggunaan Tanah Terhadap Lingkungan di Kabupaten Tangerang. Thesis. Institut Pertanian Bogor.

Marzuki, A. (2018). Analisis Tingkat Perkembangan Wilayah, Konversi Tanah dan Rasio Tanah Terdaftar serta Arahan Pengembangan Wilayah di Kabupaten Cirebon. Thesis. Institut Pertanian Bogor.

Mendoza, M. E., Granados, E. L., Geneletti, D., Perez-Salicrup, D. R. \& Salinas, V. 2011. Analysing Land Cover and Land Use Change Processes At Watershed Level: A Multitemporal Study In The Lake Cuitzeo Watershed Mexico (1975-2003). Applied Geography, 31 (1), 237-250.

Murtadho, A., Wulandari, S., Wahid, M., \& Rustiadi, E. (2018). Perkembangan Wilayah dan Perubahan Tutupan Lahan di Kabupaten Purwakarta sebagai Dampak dari Proses Konurbasi JakartaBandung. Journal of Regional and Rural Development Planning (Jurnal Perencanaan Pembangunan Wilayah dan Perdesaan), 2 (2),195-208

Pasandaran, E. (2006). Alternatif Kebijakan Pengendalian Konversi Lahan Sawah Beririgasi di Indonesia. Jurnal Litbang Indonesia, 25 (4), 123-129.

Pemerintah Republik Indonesia. (1960). Undang-Undang Republik Indonesia Nomor 5 Tahun 1960 tentang Peraturan Dasar Pokok-Pokok Agraria. Jakarta (ID): Sekretaris Negara.
Pemerintah Republik Indonesia. (2007). Undang-Undang Republik Indonesia Nomor 26 Tahun 2007 tentang Penataan Ruang. Jakarta (ID): Sekretariat Negara.

Pemerintah Republik Indonesia. (2009). Undang Undang Nomor 41 tahun 2009 tentang Perlindungan Lahan Pertanian Pangan Berkelanjutan. Jakarta (ID): Sekretariat Negara

Pribadi, D. O. \& Pauleit, S. (2015). The Dynamics of Peri-urban Agriculture During Rapid Urbanization of Jabodetabek Metropolitan Area. Land Use Policy, 48, 13-24.

Pribadi, D. O., \& Pauleit, S. (2016). Peri-urban Agriculture in Jabodetabek Metropolitan Area and its Relationship with The Urban Socio Economic System. Land Use Policy, 55, 265-274.

Pribadi D. O, Vollmer, D. \& Pauleit S. (2018). Impact peri-urban agriculture on runoff and soil erosion in the rapidly developing metropolitan area of Jakarta, Indonesia. Regional Environmental Change, 18 (3).

Rustiadi, E., Panuju, D. R. \& Saefulhakim, S. (2003). Analisis Kecenderungan dan Dampak Proses Suburbanisasi Wilayah Jabodetabek: Suatu Upaya Pengembangan Model Pembangunan Wilayah Metropolitan. Institut Pertanian Bogor

Rustiadi, E. (2007). Penataan Ruang sebagai Pengelolaan Kepentingan dan Sumberdaya Bersama. Dialog Publik Tata Ruang Nasional: Antara Kepentingan Publik dan Ekonomi, Jakarta 6 Maret 2007.

Rustiadi, E., Saefulhakim, S. \& Panuju, D. R. (2011). Perencanaan dan Pengembangan Wilayah. Crespent Press dan Yayasan Pustaka Obor Indonesia.

Ruswandi, A., Rustiadi, E. \& Mudikdjo, K. (2007). Dampak Konversi Lahan Pertanian Terhadap Kesejahteraan Petani dan Perkembangan Wilayah: Studi Kasus di Daerah Bandung Utara. Jurnal Agro Ekonomi, 25 (2), 207-219 
Sitorus, S. R. P., Putri, R. \& Panuju, D. R. (2009). Analisis Konversi Lahan Pertanian di Kabupaten Tangerang. Jurnal Tanah dan Lingkungan, 11 (2), 41-48

Trimarmanti, T. K. E. (2014). Evaluasi Perubahan Penggunaan Lahan Kecamatan di Daerah Aliran Sungai Cisadane Kabupaten Bogor. Jurnal Wilayah dan Lingkungan, 2 (1), 55-72.

Utami, W., Artika, I. G. K. \& Arisanto, A. (2018). Aplikasi Citra Satelit Penginderaan Jauh Untuk Percepatan Identifikasi Tanah Terlantar. Jurnal Bhumi. 4 (1), 53-66.

Widjayatnika, B., Baskoro, D. P. T., \& Pravitasari, A. E. (2018). Analisis Perubahan Penggunaan Lahan dan Arahan Pemanfaatan Ruang untuk Pertanian di Kabupaten Penajam Paser Utara, Provinsi Kalimantan Timur. Journal of Regional and Rural Development Planning (Jurnal Perencanaan Pembangunan Wilayah dan Perdesaan), 1 (3), 243-257.

Wulandari, S. (2018). Pola Spasial Inkonsistensi Pemanfaatan Ruang Dengan Keterkaitan Status KepemilikanPenguasaan Lahannya di Sub DAS Ciliwung Hulu. Thesis. Institut Pertanian Bogor. 